\title{
Performance Study of a Diesel Engine by using producer gas from Selected Agricultural Residues on Dual-Fuel Mode of Diesel-cum-Producer gas
}

\author{
D.K.Das ${ }^{1}$, S.P.Dash ${ }^{2}$, M.K.Ghosal ${ }^{1 *}$ \\ ${ }^{1}$ Department of Farm Machinery and Power, College of Agricultural Engineering and Technology, Orissa \\ University of Agriculture and Technology, Bhubaneswar-751003, Orissa, India \\ ${ }^{2}$ Orissa Lift Irrigation Corporation, Government of Orissa, Orissa, India. \\ * Corresponding author.Tel: +91 9556271208,E-mail: mkghosal1@rediffmail.com
}

\begin{abstract}
Of all the alternative sources of energy for rural areas, producer gas from biomass appears to have the greatest potential. As an agricultural country, India has large supply of biomass resources. It is estimated that about 40 to 60 percent of agricultural residues are either lost or put to inefficient use. This calls for better utilization of these resources by thermo-chemically converting into producer gas in the current context of limitedness of petroleum based fuels for use in internal combustion engines. Diesel engines are widely used in Indian agricultural farms for a variety of stationary and mobile operations. The usual approach of producer gas utilization in diesel engines consists of operating existing compression ignition engines on producer gas cum diesel dual-fuel mode. There is also a lack of information on the use of different types and conditions of biomass to generate producer gas as a supplement fuel for diesel engines. Therefore, an effort was made to develop a gas producer system utilizing the locally available biomass materials to power a diesel engine that can be used on small horse power tractors and stationary machines. Experiments were conducted to study the performance of a diesel engine (four stroke, single cylinder, $5.25 \mathrm{~kW}$ ) with respect to its thermal efficiency, specific fuel consumption and diesel substitution by use of diesel alone and producer gas-cum-diesel (dual fuel mode) through a downdraft gasifier. Performance of the engine was studied by keeping biomass moisture contents as $8 \%, 12 \%$, $16 \%$, and $21 \%$, engine speed as $1600 \mathrm{rpm}$ and with variable engine loads. The gas producer system developed for a $5.25 \mathrm{~kW}$ diesel engine was found to perform satisfactorily by using three types of biomass such as wood chips, pigeon pea stalks and corn cobs. The average value of thermal efficiency on dual fuel mode was found slightly lower than that of diesel mode. The specific diesel consumption was found to be 60 to $64 \%$ less in dual fuel mode than that in diesel mode for same amount of energy output. The average diesel substitution of $64 \%$ was observed with pigeon pea stalks followed by corn cobs (63\%) and wood chips (62\%). Based on the performance studied, the producer gas may be used as a substitute or as a supplementary fuel for diesel conservation, particularly for stationary engines in agricultural operations in the farm.
\end{abstract}

Keywords: Biomass gasification, Producer gas, Downdraft gasifier, Diesel engine.

\section{Introduction}

The escalating oil prices and scarcity of fuel oils coupled with exploding population have resulted in serious energy crisis. There is thus a pressing need to develop technology for utilizing the renewable energy sources that can make significant contribution to the economy and the well being of the rural people.

Of all the alternative sources of energy for rural areas, producer gas from biomass appears to have the greatest potential. As an agricultural country, India has large supply of biomass resources. It is estimated that about 40 to 60 percent of agricultural residues are either lost or put to inefficient use. This calls for better utilization of these resources by thermo-chemically converting into producer gas in the current context of limitedness of petroleum based fuels for use in internal combustion engines. Producer gas is generated from solid carbonaceous fuels such as wood, charcoal, coal, agricultural and forest residues and also animal wastes by gasification process (Hindsgaul C et.al., 2000, Dogru M. et.al., 2000, Bhattacharya S.C. et.al., 2001, G. Sridhar et.al., 2001, Das and Pandey, 1993 and Pathak and Jain, 2004). Gasification is an irreversible thermo-chemical process by which feed stock is thermally decomposed and the end products are principally in gaseous form, the main combustible components being carbon monoxide and hydrogen. The main advantages of gases as a fuel over liquid or solid 
fuels are that (i) gases burns with higher efficiency than the solid or liquid fuels, (ii) they have a higher rate of heat release (iii) the rate of energy output is easily controlled and adjustable, and (iv) gaseous fuels with good energy utilization can be used for power sources. A good quality producer gas has an energy content of about $5200 \mathrm{~kJ} / \mathrm{Nm}^{3}$. A gas producer requires 2.5 to $3 \mathrm{~kg}$ of wood to generate about the same energy as 1 liter of diesel (Tiwari and Ghosal, 2007).

Diesel engines are widely used in Indian agricultural farms for a variety of stationary and mobile operations. The usual approach of producer gas utilization in diesel engines consists of operating existing compression ignition engines on producer gas cum diesel dual-fuel mode. The thermal efficiency of gasifiers in which producer gas is produced has been found to be $70-80$ per cent and that of the gasifier-engine system to be 16-20 percent (Tiwari and Ghosal, 2007). The problem is more acute and serious in nature when producer gas is used to run motor vehicles particularly for agricultural operations. Past studies indicate that a very little effort has been made in this direction. There is also a lack of information on the use of different types and conditions of biomass to generate producer gas as a supplement fuel for diesel engines. Therefore an effort was made to develop a gas producer system utilizing the locally available raw materials to power a $5.25 \mathrm{~kW}(7 \mathrm{hp})$, single cylinder diesel engine that can be used on small horse power tractors, known as power tillers. The major objectives in this study were as follows:

(i) To fabricate the different components of a gas producer system to operate a $5.25 \mathrm{~kW}$ (7 hp) diesel engine.

(ii) To evaluate the performance of the above engine with respect to thermal efficiency, specific diesel consumption and diesel substitution by using different types of biomass.

\section{Fabrication of gas producer system}

A gas producer system consisting of a gasifier, a cooler cum cleaner unit, a filtration unit and a mixing device was designed and fabricated to operate a $5.25 \mathrm{~kW}$ diesel engine on dual fuel mode (Fig.1). A downdraft type gasifier operating under suction induced flow was designed for a maximum engine gas requirement of $10.70 \mathrm{Nm}^{3} / \mathrm{h}$ taking a maximum hearth load of 0.9 $\mathrm{Nm}^{3} / \mathrm{cm}^{2}-\mathrm{h}$. The upper part of the gasifier was the fuel container and the lower part was the hearth with ash pit. The hearth section of the gasifier was V-shaped.

The primary air intake was through a pipe extended from top to the hearth with a provision to adjust the air inlet height. The ignition tube was passed through the hearth which was closed during gasification and opened only while starting to introduce fire. Ash pit was covered with a metal filter known as grate through which ash and soot particles were collected. A hand blower was attached to the gasifier for initial charging. The cooler-cum-cleaner unit consisted of a radiator to radiate heat from hot water, a venturi to provide sufficient space for cooling the gas and a water tank. The other attachments to the cooling system were a fan driven by a $0.375 \mathrm{~kW}$ motor to lift water from the tank to the radiator. A two stage filtering unit was developed to filter the dust and soot particles. The first stage consisted of gravel, charcoal, coconut coir and cotton layers each of $15 \mathrm{~cm}$ thickness where as the second stage consisted of only two layers of cotton each of $15 \mathrm{~cm}$ thickness. Both the filtering units were packed in different boxes. 


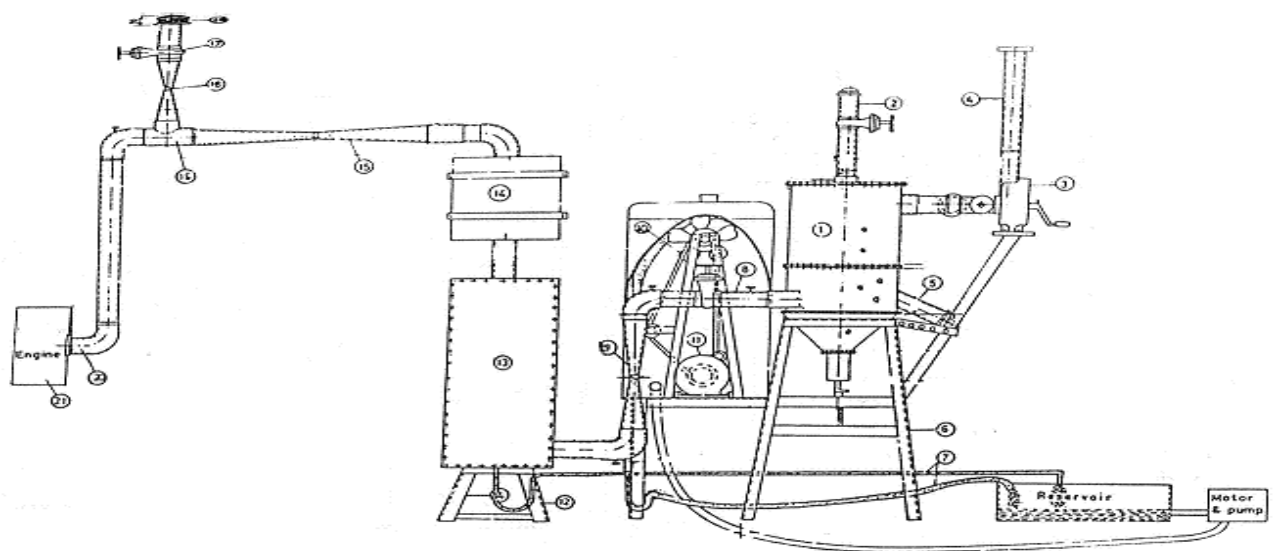
1. Gasifier
8. Gas outlet
2. Air inlet pipe
9. Gas cooling venturi
15. Gas flow venturi
3. Blower
10. Radiator and fan
4. Blower outlet
11. Fan motor
5. Ignition pipe
12. Filter stand
6. Gasifier stand
13. Primary filter
16. Air flow venturi
7. water pipe with $U$ bends
14. Secondary filter
17. Air control gate valve
18. Air filter
19. Air gas mixing device
20. Intake manifold
21. Diesel engine

Fig. 1 A gas producer system.

\section{Methodology}

A single-cylinder 4-stroke $5.25 \mathrm{~kW}$ diesel engine of a commercial power tiller was used for the experiment. The intake manifold of the engine was modified using a T-section to introduce the mixture of air and gas into the engine during suction stroke. The quantities of gas and air flowing to the engine were measured separately with the help of two venturi sections provided in the T-section. The U-tube manometers were connected to the venturi section with polythene tube to measure the pressure drop across them. The original fuel supply of the engine from its fuel tank was cut-off for the operation on dual fuel mode and the diesel fuel was supplied from an auxiliary tank provided with a fuel measuring set-up. In order to measure the load applied to the engine, a prony brake dynamometer was used. A strain gauge transducer was used to measure the temperatures of oxidation and reduction zones in the gasifier and the exit gas from the gasifier and the filtration unit.

\subsection{Performance evaluation of engine}

The diesel engine (specifications given in Table-1) was tested on diesel as well as on dual fuel mode at the engine speed $1600 \mathrm{r} / \mathrm{min}$ and six loads $(7.5 \mathrm{~N}, 12.5 \mathrm{~N}, 20 \mathrm{~N}, 30 \mathrm{~N}, 40 \mathrm{~N}$ and $50 \mathrm{~N})$. The composition of the gas was also studied $\left(\mathrm{CO}=22.8 \% ; \mathrm{CO}_{2}=7.2 \% ; \mathrm{O}_{2}=0.5 \%\right.$ and other gases $=69.50 \%$ ). For dual fuel operation, the types of biomass used were wood chips, pigeon pea stalks and corn cobs. Three materials were used at four different moisture contents $(8,12$, 16 and 21 percent on wet basis). Each test was conducted for a period of 5 minutes with two replications. During each test on diesel, the engine load, engine speed and fuel consumption were measured. The observed data were utilized to calculate the engine thermal efficiency, specific diesel consumption and percent diesel substitution. The performance of a diesel engine operated on dual-fuel mode was generally evaluated in terms of specific diesel consumption, engine thermal efficiency and per cent diesel substitution. These parameters were determined as follows,

a) Specific diesel consumption (SCD) : SDC is given by 
$\mathrm{SDC}=\frac{3600 v_{d} \rho_{d}}{1000 t p}=3.6 \frac{v_{d} \rho_{d}}{t p}$

where SDC = specific diesel consumption, $\mathrm{g} \mathrm{kW}^{-1} \mathrm{~h}^{-1} ; v_{d}=$ volume of diesel consumed, $\mathrm{cm}^{3}$, $\rho_{d}=$ specific weight of diesel, $\mathrm{kg} / \mathrm{l} ; \mathrm{t} \quad=$ time required to consume $v_{d}$ in second; and $p=$ engine power, kw.

b) Thermal efficiency: The thermal efficiency is expressed as the ratio of output power to the power supplied by the fuel.

i) Thermal efficiency of engine on diesel alone: Thermal efficiency of engine on diesel alone is given by

$\eta_{\mathrm{t}}=\frac{\text { Brake power }}{\text { Power input from fuel }}$

The power input from fuel in eqn. (2) is given by

$p_{f}=\frac{c v_{d} \times \rho_{d} \times f_{c}}{3600}$

Where $p_{f}=$ Power input from fuel, $\mathrm{kW} ; c v_{d}=$ calorific value of diesel $=39 \mathrm{MJ} / \mathrm{kg}$

$\rho_{d}=$ densityof diesel $=640 \mathrm{~kg} / \mathrm{m}^{3}$; and $f_{c}=$ fuel consumed, $\mathrm{cm}^{3} / \mathrm{h}$. Substituting the values of

$c v_{d}$ and $\rho_{d}$, the eqn (3) yields

$\mathrm{P}_{\mathrm{f}}=\frac{39 \times 840 \times \mathrm{f}_{\mathrm{c}}}{3600}=9.1 f_{c}$

Using eqn (4.), eqn (2) gives

$\eta_{t}=\frac{\text { Brake power }}{9.1 f_{c}}$

ii)Thermal efficiency of engine on dual fuel mode

The formula used for calculating the thermal efficiency of engine on dual fuel mode is given by

$$
\eta_{\mathrm{t}}=\frac{\text { Brake power }}{\text { Power input from pilot diesel }+ \text { power input from gas }}
$$

Power input from producer gas is given by

$$
p_{g}=\frac{C V_{g} \times g_{c}}{3.6}
$$

where $p_{g}=$ power from producer gas, $\mathrm{kW} ; c v_{g}=$ calorific value of producer gas, $\mathrm{KJ} / \mathrm{Nm}^{3}$; and $g_{c}=$ gas consumption, $\mathrm{Nm}^{3} / \mathrm{h}$. Substituting eqns. (5) and (7) in eqn. (6),

$$
\eta_{t}=\frac{\text { Brake power }}{9.1 f_{c}+\frac{C V_{g} \times g_{c}}{3.6}}
$$


iii) Diesel substitution: The per cent diesel substitution is given by

$d s=\frac{D_{d}-D_{d g}}{D_{d}} \times 100$

Where $d s=$ diesel substitution, per cent; $D_{d}=$ diesel consumption by the engine on diesel alone, $\mathrm{cm}^{3} / \mathrm{h}$; and $D_{d g}=$ diesel consumption by the engine on dual fuel mode, $\mathrm{cm}^{3} / \mathrm{h}$.

Table-1 Specifications of gas producer engine system under test

I. Engine
(a) Type
(b) Number of cylinder
4-stroke cycle diesel engine
(c) Cylinder capacity (cc)
1
(d) Bore (mm)
450
(e) Stroke (mm)
80
(f) Crank shaft speed (rated), r/min
90
(g) Rated capacity $(\mathrm{kW})$
2200
(h) Grade of oil
5.25
(i) Fuel
(j) Cooling system
SAE 30
High speed diesel
Water-cooled

II. Gasifier

(a) Type

(b) Material of construction

(c) Hearth opening (mm)

Moving bed, co-current Down draft

Mild steel

(d) Grate mesh size $(\mathrm{mm})$

60

(e) Total weight (kg)

10

37

\section{Results and discussion}

The relationship between engine load and thermal efficiency at the four levels of moisture content (8\%, 12\%, 16\% and 21\%) for the different types of biomass (wood chips, pigeon pea stalks, corn cobs) is shown in Figs. 2, 3 and 4 at engine speed of $1600 \mathrm{r} / \mathrm{min}$. The trend shows that the thermal efficiency increased with a decreasing rate with increase in engine load for all the biomass fuels at all the biomass moisture levels tested. This may be due to better combustion of relatively rich gas-air mixture at higher loads. It is also observed that with increase in biomass moisture from 8 to 21 per cent, the thermal efficiency also increased marginally from 28 to 31 per cent with wood chips, 30 to 32 per cent with pigeon pea stalks and 29 to 32 per cent with corn cobs. The slight increase in thermal efficiency from 8 to 21 per cent moisture range might have been caused due to better combustion of premixed mixture of gas and air on dual-fuel mode resulting in reduced requirement of total energy input at different loads.

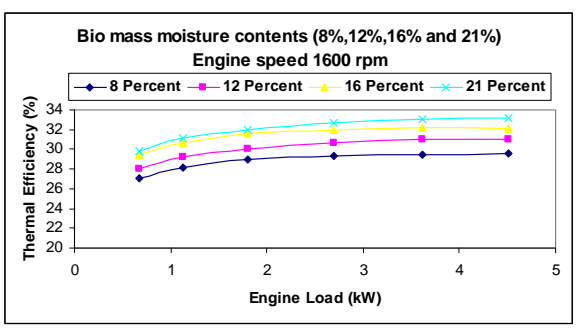

Fig. 2 Variation of thermal efficiency with engine load on dual fuel mode at different moisture contents of wood chips

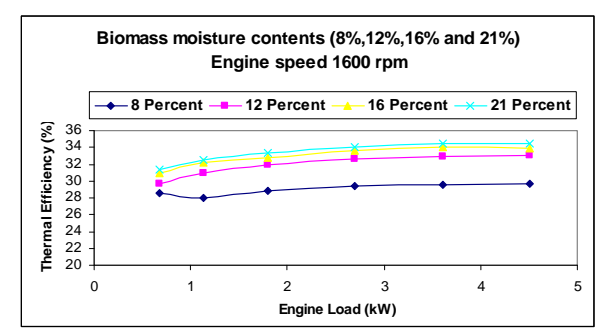

Fig. 3 Variation of thermal efficiency with engine load on dual fuel mode at different moisture contents of pigeon pea stalks 


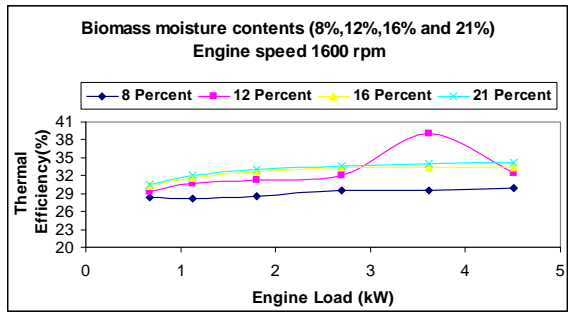

Fig. 4. Variation of thermal efficiency with engine load on dual fuel mode at different moisture contents of corn cobs

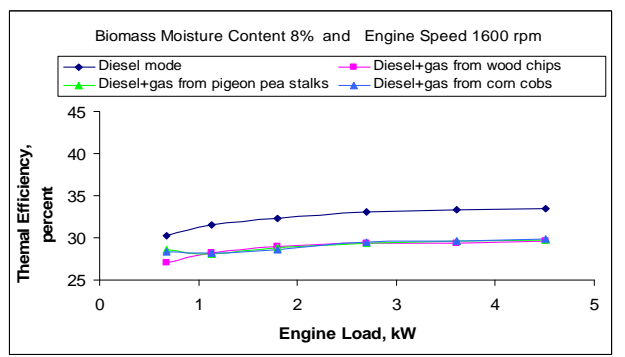

Fig. 5 Effect of engine load on thermal efficiency with different types of fuel

The effect of different types of fuel on engine thermal efficiency at $1600 \mathrm{r} / \mathrm{min}$ is shown in Fig. 5. The trend showed that there was a slight drop in thermal efficiency of engine on dualfuel mode, compared to that on diesel alone. Based on mean values, it may be reported that the thermal efficiency of diesel engine when tested, dropped from 32.3 per cent on diesel fuel mode to 30.5 per cent on dual-fuel mode using wood chips. However, the efficiency of engine on dual-fuel mode using pigeon pea stalks and corn cobs was found almost at par with that on diesel mode. This showed that the combustion of air-gas mixture while using pigeon pea stalks and corn cobs was better compared to wood chips, even though the energy content of wood chips was relatively high. The variation of specific diesel consumption and diesel substitution with engine load on dual-fuel mode of a diesel engine at different biomass moisture levels has been shown in Figs. 6 through 11. The trend of the curves showed that the specific diesel consumption, in general, decreased with increase in engine load at different moisture levels for all the three types of biomass used. However, a definite trend of variation of diesel substitution with engine load has not been established. It has shown increasing trend with load in most of the cases, whereas in a few cases a decreasing pattern has also been observed. This kind of trend is not uncommon in the existing literatures. It is usually reported that if the energy content of the gas remains relatively stable, a higher load means a higher consumption of diesel fuel and thus a lower percentage of diesel fuel displacement. But if the quality of the gas in terms of its energy content is not stable, an increase in load can also increase the percentage of diesel fuel substitution. The decrease in specific diesel consumption with load is primarily due to increase in diesel fuel consumption at a decreasing rate. From the mean values of specific diesel consumption and diesel substitution in the test engine at different operational parameters (taking all loads into consideration), it was observed that the specific diesel consumption of engine on dual-fuel mode using wood chips decreased from $87.9 \mathrm{~g} / \mathrm{kWh}$ at 8 per cent moisture level to $75.9 \mathrm{~g} / \mathrm{kWh}$ at 12 per cent moisture level beyond which it again increased and rose to $161.8 \mathrm{~g} / \mathrm{kWh}$ at a biomass moisture level of 21 per cent. The diesel substitution on the other hand, varied from 50.5 to 68.8 per cent in the same moisture range showing maximum value of 72.3 per cent at a moisture level of 12 per cent. Similar trends of variation of specific diesel consumption and diesel substitution were also noticed in case of the other two biomass fuels. For the sake of comparison, the minimum values of specific diesel consumption using pigeon pea stalks and corn cobs were observed to be 82 and $87 \mathrm{~g} / \mathrm{kWh}$ respectively, whereas the maximum values of diesel substitution for these fuels was found to be about 71.3 per cent at a moisture level of 12 per cent. This showed that the minimum values of specific diesel consumption were derived at a particular biomass moisture level (12 per cent) where diesel substitution was maximum. This was perhaps due to better quality of gas obtained at this moisture level as reflected by its higher $\mathrm{CO}$ content resulting in better combustion of air gas mixture. The variation of specific diesel consumption with engine load for the test engine on diesel mode as well as on dual-fuel mode using different types of biomass is shown in Fig. 12 for a particular set of operating 
parameters. The data indicated a slight decrease in specific diesel consumption with engine load both on diesel as well as on dual fuel operations. As expected, the specific diesel consumption on diesel mode is much higher than that on dual-fuel mode for all the engine loads tested. Comparing the performance of engine on the basis of the mean values of specific diesel consumption, it was observed that the engine consumed 60 to 64 per cent less diesel on dual-fuel mode than that on diesel mode for the same amount of energy output. The effect of engine load on per cent diesel substitution for different types of biomass is shown in Fig. 13. The trend showed increasing pattern of diesel substitution with engine load as explained earlier. Based on the mean values of diesel substitution, it can be pointed out that the average diesel substitution of 64 per cent was found with pigeon pea stalks followed by corn cobs (63 per cent) and wood chips (62 per cent) throughout the range of biomass moisture. From the results discussed above, it can be stated that the gasifier system developed for $5.25 \mathrm{~kW}$ diesel engine has indicated satisfactory performance by showing, on an average 60 to 65 percent saving in diesel consumption while utilizing three types of locally available biomass fuels.
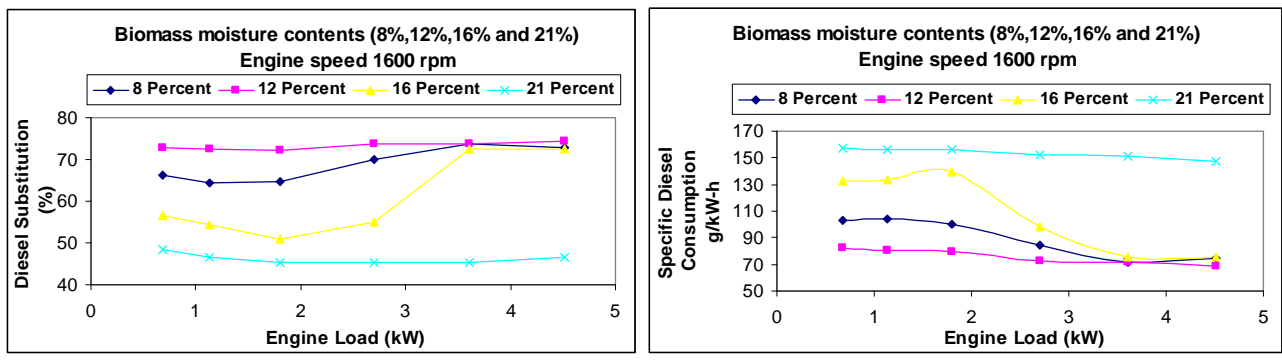

Fig. 6. Variation of specific diesel consumption with engine load on dual fuel mode at different moisture contents of wood chips

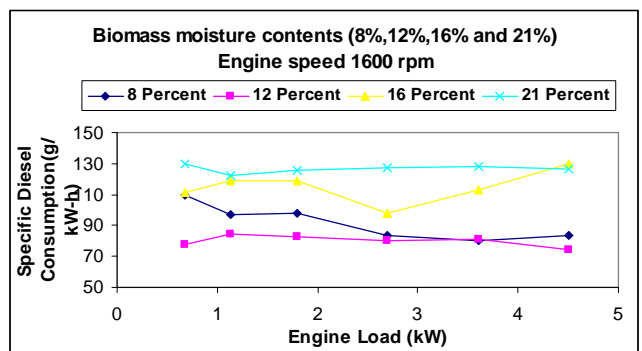

Fig. 8. Variation of specific diesel consumption with engine load on dual fuel mode at different moisture contents of pigeon pea stalks

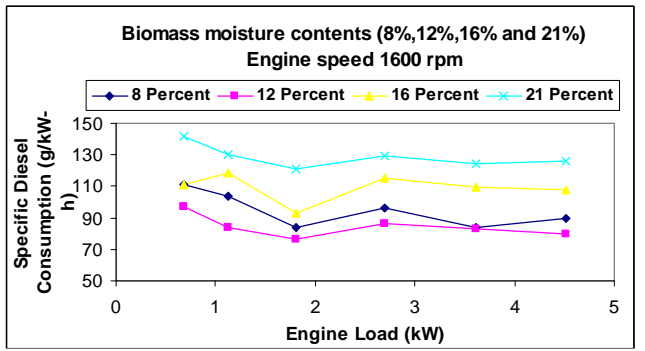

Fig. 10. Variation of specific diesel consumption with engine load on dual fuel mode at different moisture contents of corn cobs
Fig. 7. Variation of diesel substitution with engine load on dual fuel mode at different moisture contents of wood chips

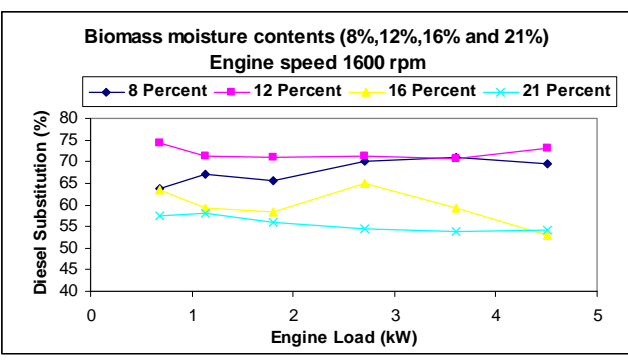

Fig. 9. Variation of diesel substitution with engine load on dual fuel mode at different moisture contents of pigeon pea stalks

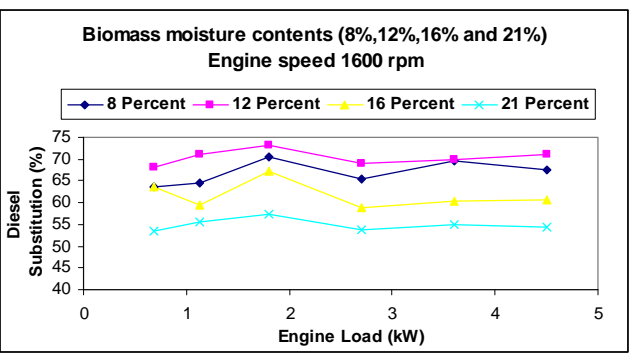

Fig. 11. Variation of diesel substitution with engine load on dual fuel mode at different moisture contents of corn cobs 


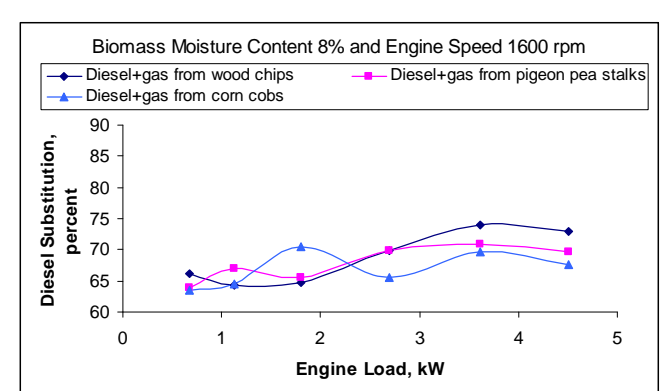

Fig. 12. Effect of engine load on specific diesel consumption with different types of fuel

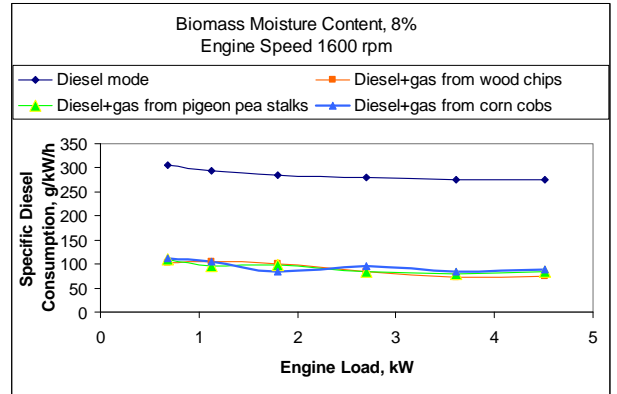

Fig. 13 Effect of engine load on diesel substitution with different types of fuel

\section{Conclusions}

Based on the studies conducted, the following conclusions may be drawn.

(i) The gas producer system designed and developed for a $5.25 \mathrm{~kW}$ diesel engine was found to perform satisfactorily by using different types of biomass such as wood chips, pigeon pea stalks and corn cobs.

(ii) The average value of thermal efficiency of engine was found to drop slightly from 32.3 percent on diesel mode to 28.7 percent on dual fuel mode using wood chips as biomass fuel. However the efficiency found on dual fuel mode with pigeon pea stalks and corn cobs was comparable to that on diesel mode.

(iii) The mean values of specific diesel consumption of engine on dual-fuel mode for all the three biomass fuels were less compared to diesel mode and their diesel substitution was more.

(iv) The average diesel substitution in a $5.25 \mathrm{~kW}$ diesel engine was found in the range of 62 to 64 percent using three types of biomass fuels.

The above findings presented in this paper would provide useful information to all those engaged in design, manufacture and use of gasifier system for satisfactory and mobile operation of stationary engine used in agricultural purposes.

\section{References}

[1] C. Hindsgaul, J. Schramm, L.Gratz, U. Henriksan, and J.D. Bentzen, Physical and chemical characterization of particles in producer gas from wood chips, Bio Resource Technology 73, 2000, pp. 147-155.

[2] M. Dogru, C.R. Howarth, G. Akay, B. Keskinler and A.A. Malik, Gasification of hazelnut shells in a downdraft gasifier, Energy, 27, 2000, pp. 415-427.

[3] S.C.Bhattacharya, Hla. San Shwe, and Hoang-Luang. Pham, A study on a multi-stage hybrid gasifier-engine system. Biomass and Bioenergy 21, 2001, pp. 445-460.

[4] G.Sridhar, P.J.Paul, and H.S.Mukunda, Biomass derived producer gas as a reciprocating engine fuel-an experimental analysis. Biomass and Bioenergy 21, 2001, pp. 61-72.

[5] D. K. Das, and K P. Pandey, Some studies on biomass based gas producer system for a diesel engine. Unpublished Ph.D. thesis, 1993, Agril.Engineering Department, IIT, Kharagpur.

[6] B. S.Pathak, and A. K.Jain, Engine quality producer gas from leucaena leucocephala and selected agricultural residues. J. of Agril. Engineering 21(3), 2004, pp. 43-50.

[7] G.N.Tiwari and M.K.Ghosal, Fundamentals of Renewable Energy Sources: Basic Principles and Applications. Narosa Publishing House, New Delhi, 2007. 